\title{
The Intersection of Labour and Refugee Policies in the Middle East and Turkey: Exploring the Dynamics of "Permanent Temporariness"
}

\author{
Souad Osseiran
}

\begin{abstract}
The majority of Syrian refugees who have migrated to neighbouring countries in the Middle East and Turkey are faced with being "permanently temporary," whether this temporariness defines their legal status, or state actor policies targeting refugees. The permanent temporariness of Syrian refugees in the region, while reinforced by various (non-)state actors, and produced differently based on the history and asylum framework of nation states in the region, aims primarily at incorporating Syrian refugees into local economies as surplus labour. This paper seeks to examine the incorporation of refugees as labour in relation to the development of migration governance in the region. Refugees as labour is used to conceptualize how refugees, as a type of mobile population, are approached as a desirable source of labour power due to their precarious position and permanently temporary presence. As such, the paper critically evaluates the ways in which refugees as labour are normalised. Lastly, it seeks to enquire how this impacts refugeehood as a political-legal concept.
\end{abstract}




\section{Introduction}

With this special issue's focus on responses to displacement in the Middle East and Turkey, the included articles explore the ways different state and non-state actors have been engaging with Syrian refugees, as well as how migration policies across the region influence refugee experiences. A spectrum of actors ranging from state actors, non-governmental institution members to educators, employers or even neighbours and fellow refugees affect Syrian refugees' experiences of their forced migration in varied and multiple ways. I argue that Syrian refugees' presence in countries across the Middle East, with a focus on Jordan and Lebanon, and Turkey, is constituted as temporarily present and that this temporariness is tied to Syrian refugees' position as a precarious and exploitable labour power. In examining the issue of temporality in this refugee context, I aim to situate the ways in which refugees in the region are incorporated ${ }^{1}$ into existing hierarchies and relations of exploitation, while highlighting how temporariness marks their relations with state and non-state actors. The normalisation of refugees' position as labour ${ }^{2}$ in countries across the Middle East and Turkey must be critically evaluated. This paper builds on existing discussions examining refugees' positions in states across the region as labour, ${ }^{3}$ as well as literature from outside the region exploring experiences of "precarious non-citizenship."

Non-citizenship includes a spectrum of legal statuses, that vary depending on the migration regime in question. ${ }^{5}$ Non-citizen legal statuses such as long-term residence, temporary work permits, short term touristic residence permits, spousal visas, asylum seeker status, duldung or temporary suspension of deportation, ${ }^{6}$ temporary protection, ${ }^{7}$ tolerated stay ${ }^{8}$ among

\footnotetext{
1"Incorporation" is not used in this paper in the positive sense as it is commonly associated with the term "integration." Incorporation is relied on in order to discuss refugees' labour and presence while recognising the exploitative nature of labour relations. While much of the host societies in the three countries under study, object to refugee's incorporation as labour, blaming refugees for loss of jobs or negatively affecting wages, these arguments fail to blame employers and capitalist relations for the ways in which refugee labour, as cheaper labour, becomes desired.

2"Refugees as labour" moves from Samaddar's comments about refugees as labouring subjects, and Rajaram's analysis that "migrants and refugees do not simply move, they move as potential labour power, to be incorporated (or not) into modes of production" (p.632). See: Ranabir Samaddar,"The Labour of the Refugee Economies," Website, Refugee Watch, 2017, available at:

https://refugeewatchonline.wordpress.com/2017/04/14/the-labour-of-the-refugee-economies/ [Last accessed on 16 December 2019]; Prem Kumar Rajaram, "Refugees as Surplus Population: Race, Migration and Capitalist Value Regimes," New Political Economy, 2018, Vol. 23(5), p.627-639.

${ }^{3}$ Katharina Lenner and Lewis Turner,"Making Refugees Work? The Politics of Integrating Syrian Refugees into the Labour Market in Jordan," Middle East Critique, 2019, Vol.28(1), 65-95; Lewis Turner, "Explaining the (Non-)Encampment of Syrian Refugees: Security, Class and the Labour Market in Lebanon and Jordan," Mediterranean politics, Vol. 20(3), p. 386-484.

${ }^{4}$ Luin Goldring and Patricia Landolt, "The Conditionality of Legal Status and Rights: Conceptualising Precarious Non-citizenship in Canada," In Luin Goldring and Patricia Landolt (eds.), Producing and Negotiating Non-Citizenship: Precarious Legal Status in Canada, Toronto,University of Toronto Press, 2013, p. 3-28. ${ }^{5}$ Ibid.

${ }^{6}$ Heidi Castaneda, "Deportation Deferred: "Illegality," Visibility, and Recognition in Contemporary Germany," In Nicholas De Genova and Nathalie Mae Peutz (eds.), The Deportation Regime: Sovereignty, Space, and the Freedom of Movement, Durham, Duke University Press, 2010, p.245-261.

${ }^{7}$ Luin Goldring, Carolina Berinstein and Judith K. Bernhard, "Institutionalizing precarious migratory status in Canada," Citizenship Studies, 2009, Vol. 13(1), p.239-265.

${ }^{8}$ Michal Sipos, “'We are all brothers here': The making of a life by Chechen refugees in Poland," Population, Space and Place, e2276, p.1-11.
} 
others highlight the multiplicity that exists within this spectrum. ${ }^{9}$ These statuses are contingent and conditional as migrants or refugees may move between these statuses in some cases by fulfilling certain conditions, or fall into "less secure" status by failing to meet conditions. ${ }^{10}$ In their discussion, Landolt and Goldring highlight the ways various actors influence migrants' movement between non-citizen statuses. ${ }^{11}$ For example, employers' refusal to renew the contract of migrant workers could result in their presence becoming "unauthorised" unless they secure another job that provides a work permit or acquire another status as students, spouse or the like. They argue that various actors beyond state actors affect migrants' statuses by facilitating migrants' access to more secure status or services or pushing them towards more precarious status. ${ }^{12}$ With a focus on the Canadian context, Rajkumar and co-authors ${ }^{13}$, outline the multiplicity of non-citizen statuses that are used and emphasise the ways temporary presence or status is increasingly becoming the norm. Their argument nuances discussions about non-citizen statuses by examining the conditions underlying these statuses, the forms of permanence possible, or embedded time constraints. They explore the link between statuses' and citizenship, as some statuses allow holders to qualify for citizenship processes, while others permanently exclude them from qualifying. ${ }^{14}$ Drawing on their approach, I adopt the qualification of "permanently temporary" context of the Middle East and Turkey, to further analyse the modes of refugee incorporation.

With the goal of contributing to a wider discussion at the intersection of political economy and migration, this paper draws on existing research examining refugees' incorporation as labouring subjects. ${ }^{16}$ Samaddar highlights the ways in which research in refugee studies focuses on employment but avoids discussing refugees as labouring subjects. ${ }^{17}$ A discussion about refugee employment from a policy perspective, or debates focussing on informal-formal employment, may depoliticise investigations of labour relations. Analysing

\footnotetext{
${ }^{9}$ For general discussion, see: Luin Goldring and Patricia Landolt, op.cit., 2013; Rajkumar et al., op.cit., 2012.

${ }^{10}$ In the spectrum between "citizenship" and "unauthorised presence," the majority of legal statuses include conditions or criteria that must be met to continue to hold the status. Failing to meet the conditions result in a loss of status. At the same time, even statuses such as citizenship, which are perceived as more stable, can be lost, as in the case of individuals giving up one citizenship to enter another, or in situations in which citizenship is revoked - as in the most recent cases of European nationals who joined the Islamic State of Iraq and Syria. See: Luin Goldring and Patricia Landolt, op.cit., 2013, p.9.

${ }^{11}$ Ibid.

${ }^{12}$ Ibid.

${ }^{13}$ Rajkumar et al., "At the Temporary-Permanent Divide: How Canada Produces Temporariness and Makes its Citizens Through its Security, Work and Settlement Policies," Citizenship Studies, 2012, Vol. 16(3-4), p.485-510 ${ }^{14}$ Ibid.

${ }^{15}$ Rajkumar et al. use "permanently temporary" to refer to migrant labour arriving on visas to work in the agricultural sector in Canada, who can only be present for a set length of time. While in this displacement case in the Middle East and Turkey, the length of time refugees can remain is not set, the eventual return (forced or voluntary) or onward migration underlies the refugee presence, See: International Crisis Group, "Easing Syrian Refugees' Plight in Lebanon," Brussels, International Crisis Group, 2020, p.211, available at: https://www.crisisgroup.org/middle-east-north-africa/eastern-mediterranean/lebanon/211-easing-syrian-refugeesplight-lebanon [Last accessed on 19 February 2020].

Rajkumar et al. explain other categories of temporarily permanent and temporarily temporary, but for the context of this discussion, permanently temporary is the most useful approach in this analysis. See: Rajkumar et al., op.cit., 2012, p.485.

${ }^{16}$ Prem Kumar Rajaram, op.cit., 2018; Moritz Altenried et al., "Logistical Borderscapes: Politics and Mediation of Mobile Labour in Germany after the 'Summer of Migration," South Atlantic Quarterly, 2018, Vol. 117(2), p.291-312.

${ }^{17}$ Ranabir Samaddar, op.cit., 2017.
} 
refugees as labour, however, is, firstly, intellectually productive to explore the relations being formed with citizens, state and non-state actors across the region. Secondly, it enables the examination of the tension between refugees' experience of forced migration and the legal and political status of 'refugee'. Moreover, approaching refugees as labouring subjects blurs the distinction between migrant and refugee which, as will be argued below, is a visible characteristic of migratory regimes within the region. ${ }^{18}$

Through his analysis of refugees as labour, Rajaram offers a critique of research that fails to recognise the ways in which existing social, racial and hierarchical relations affect refugees' position in society. ${ }^{19}$ Using the example of how the public and state actors' responded to the arrival of migrants and refugees to Hungary in 2015, he links these responses to policies and discourses evoked in the case of Hungary's Roma population. The Roma population is constructed as an "other" to an imagined ideal public, and this construction is then used as grounds to develop and implement policies targeting this population. Focusing on the practices to govern populations, Rajaram demonstrates how similar policies and practices used in the case of the Roma were implemented with the arrival of refugees and migrants in $2015 .{ }^{20}$ The figure of the refugee or migrant developed was one closer to the internal "other" - the Roma - providing moral grounds to support evicting them from public spaces or other more extreme measures. This type of analysis identifies how various actors, state, society among others, approach refugees and/or migrants based on already operative relations; thus, refugees and/or migrants are incorporated into existing hierarchies and relations. I draw on Rajaram to analyse the ways in which refugees are incorporated in states across the Middle East and Turkey, while accounting for the differential inclusion of various individuals whether citizens, permanent residents, refugees, and migrants based on social and economic relations. ${ }^{21}$ In the following, I examine how this inclusion takes shape for Syrian refugees in the region and the underlying productivity of including refugees as labour across the region. In the process, I argue that Syrian refugees in the Middle East and Turkey are incorporated as permanently temporarily present and their presence as labour is normalised.

\section{Migratory Regimes: Institutionalising "Permanent Temporariness"}

A theoretical discussion about the migratory politics and/or policies implemented across the Middle East and Turkey requires revisiting the territorial borders of the region. Since their independence, states in the region have been shaped by distinct histories, and as such, analysing them within the same framework can only be possible by blurring their territorial borders. Historically, the Middle East region and Turkey have been the site for many migration movements, forced or voluntary, over the years, even prior to becoming the territorially bounded nation states that we know today. ${ }^{22}$ Migrations in the region in the twentieth century have shaped current migratory policies and politics surrounding

\footnotetext{
${ }^{18}$ Migratory regimes in European Union (EU) states or the United States of America (USA) are less visibly focused on organising labour migration, with migration prevention or management being more visible. However, the incorporation of migrant labour in these states is a key aspect of the migratory regimes in place.

${ }^{19}$ Prem Kumar Rajaram, op.cit., 2018.

${ }^{20}$ Ibid.

${ }^{21}$ Ibid.; Sandro Mezzadra and Brett Neilson, Border as Method, or, the Multiplication of Labor, Durham, Duke University Press, 2013.

${ }^{22}$ Dawn Chatty, Displacement and Dispossession in the Middle East, Cambridge, Cambridge University Press, 2010 .
} 
citizenship and asylum in different states in the Middle East and Turkey. Equally, current politics surrounding migration in the Middle East and Turkey do not only stem from previous migrations but also from broader, international migratory regimes that aim to govern migration and mobility not only in countries close to the $\mathrm{EU}^{23}$ but even in geographies much further afield. ${ }^{24}$ Various migration scholarship has analysed the ways in which migratory regimes act to control - temper - migration rather than prevent it, despite the appearance of working to prevent migration. ${ }^{25}$ In their discussions about migratory regimes, various authors demonstrate the ways border securitisation, deportation, detentions and externalisation of borders to far beyond territorial state borders in reality, rather than preventing migration, set the terms for the inclusion of those who "manage" to make it to their destination country. ${ }^{26}$ Their analysis of the operation of migratory regimes, which connects the labour incorporation of migrants (and/or refugees) with border and migration control mechanisms, presents a lens to analyse the migratory regimes developing in the region.

State and non-state actors within the Middle East and Turkey constitute the migratory regimes that govern not only migratory movements, but also the presence of migrants and refugees within the region. ${ }^{27}$ Furthermore, these regimes impact migration from the region, as well, whether through resettlement to third countries programs or migrants and refugees crossing borders themselves to arrive in Europe or elsewhere. Although, unlike Turkey, Lebanon and Jordan do share borders with any European Union member states, they have been the object of border externalisation processes. As a result of the recent displacement, they have received humanitarian-development style aid that is seemingly aimed at ensuring that the refugee population remains in these countries or returns to their home countries -

\footnotetext{
${ }^{23}$ Sabine Hess, "De-naturalising transit migration. theory and methods of an ethnographic regime analysis," Population, Space and Place, 2010, Vol. 18(4), p.428-440.

${ }^{24}$ For discussion on West African states, see: Ruben Andersson, Illegality, inc.: Clandestine Migration and The Business of Bordering Europe, California Series in Public Anthropology, California, University of California Press, 2014.

${ }^{25}$ Dimitris Papadopoulos, Niamh Stephonson and Vassilis Tsianos, Escape Routes: Control and Subversion in the Twenty-First Century, London, Pluto Press, 2008; Rutvica Andrijasevic, "From exception to excess: detention and deportations across the Mediterranean space." In Nicholas De Genova and Nathalie Mae Peutz (eds.), The Deportation Regime: Sovereignty, Space, and the Freedom of Movement, Durham, Duke University Press, 2010, p.147-165; Sandro Mezzadra and Brett Neilson, op.cit., 2013.

${ }^{26}$ Ruben Andersson, op.cit., 2014; Sandro Mezzadra and Brett Neilson, op.cit., 2013; Nicholas De Genova, "The Deportation Regime: Sovereignty, Space, and the Freedom of Movement," In Nicholas De Genova and Nathalie Mae Peutz (eds.), The Deportation Regime: Sovereignty, Space, and the Freedom of Movement, Durham, Duke University Press, 2010, p.507.

${ }^{27}$ Hess and Papadopoulos, Stephenson and Tsianos explain migratory regimes as including multiple actors whether state or non-state, whether non-governmental organisations, international institutions (e.g. IOM or UNHCR) or even private companies (e.g. visa processing centres) that are engaged in migration governance. Migrants and refugees do not just deal with state actors but various actors with different agendas who are part of the migratory regime. This paper builds on their approach. See: Sabine Hess, op.cit., 2010; Dimitris Papadopoulos, Niamh Stephonson and Vassilis Tsianos, op.cit., 2008.
} 
but in any case do not attempt to migrate towards Europe. ${ }^{28,29}$ Countering the idea of these states as mere beneficiaries of aid, Adamson and Tsourapas highlight the ways in which migration regimes in the region have turned to the "commodification of forced displacement" as a method to gain financial, economic or political support for hosting refugees..$^{30}$ Governments in Lebanon and Jordan turned to calling for support from the European Union, United States of America and major donors for hosting Syrian refugees and for the insufficient or weak national infrastructure to cope with the refugee presence. ${ }^{31}$ Beyond commodifying refugee presence, migratory regimes in the region are mainly organised to manage and control migrant labour, rather than provide for refugee presence or rights as will be discussed later on in this article.

For refugees in the Middle East and Turkey, long-term temporariness has been institutionalised as a norm. However, within the region, temporary forms of protection vary from being a legal status as in the case of Turkey, to the unlegislated versions existing in Lebanon and Jordan. I argue that the migratory regimes in place in Lebanon and Jordan rely on state actors using temporary forms of protection as a strategy to govern refugee presence. One could argue that generally, migratory regimes in the Middle East are distinguished by the way in which permanent temporariness is the "margin" assigned to "tolerate" the presence of refugees, in the absence of legal forms of protection. Various Middle Eastern countries have been hosting large Palestinian refugee populations since the Nakba in 1948, and following subsequent migration waves, but remain non-signatories of the 1951 Convention Relating to the Status of Refugees or its 1967 protocol. Turkey, although a signatory, maintains a geographical limitation whereby only asylum seekers from Europe may be granted refugee status, and the possibility of applying for citizenship (Law 6458). Refugees from outside Europe are granted protection with the expectation that they will be resettled later on to a third country through refugee resettlement programs (Law 6458). ${ }^{32}$

\footnotetext{
${ }^{28}$ The Regional Response and Resilience Plan (annual reports), the Jordan Compact (2016), the Turkey-EU Deal (2016) are examples of this humanitarian-development nexus as well as various states' promises of aid and support, such as the Friends' of Syria meeting. Aid, funding and programs are promoted to alleviate the "burden" posed by refugee presence in countries in the region and to support local economies and national institutions to cope with the increase in population, while also seeking to reduce tensions or conflict due to refugee presence. The framing hides the shifting politics surrounding discourses of burden sharing, the failure of this approach, as well as never addressing socio-economic, and therefore political, issues within the host countries themselves. See: Fiona B. Adamson and Gerasimos Tsourapas, "The Migration State in the Global South: Nationalising, Developmental, and Neoliberal Models of Migration Management," International Migration Review, 2019, p.1-30.

${ }^{29}$ Nergis Canefe, The Syrian Exodus in Context: Crisis, Dispossession and Mobility in the Middle East, Istanbul, Istanbul Bilgi University Press, 2018.

${ }^{30}$ Fiona B. Adamson and Gerasimos Tsourapas, op.cit., 2019, p.17.

${ }^{31}$ Ibid.

${ }^{32}$ The title of the status changed and based on the current law they are referred to as conditional refugees (Law 6458; Article 62) where under previous regulation refugees from outside Europe were referred to as asylum seekers even when status determination was positive. See: Directorate General of Migration Management, "Regulation No. 1994/6169 on the Procedures and Principles related to Possible Population Movements and Aliens Arriving in Turkey either as Individuals or in Groups Wishing to Seek Asylum either from Turkey or Requesting Residence Permission in order to Seek Asylum From Another Country” adopted on January 19, 1994, available at: http://www.refworld.org/docid/49746cc62.html [Last accessed 16 December 2019]; Directorate General of Migration Management, "Law No. 6458 on Foreigners and International Protection," adopted April 4, 2013, available at: https://www.refworld.org/docid/5167fbb20.html [last accessed 13 December 2019]
} 
In the case of Palestinian refugees living in countries across the Middle East, it was not the right to protection that was brought to the forefront in the politics surrounding their presence, but the right to return. With geo-politics that continues to emphasis the "right" to return, Palestinian refugees have remained caught in the status of "refugee" in Lebanon and Syria and to a lesser extent Jordan. Simultaneously, their associated rights and obligations vary by country and have been influenced by key historical developments of nation states in the region. ${ }^{33}$ Despite these differences, the right to return, as well as Palestinian refugees' limited legal, social and economic rights as non-citizens, mark their differential inclusion in society. $^{34}$

Refugees who arrived after the initial forced migration whether from Palestine in 1967, from Iraq as of 2003, from Syria as of 2011, or from other countries, have faced varying situations of de facto incorporation into the economy, without access to basic human rights for the most part. ${ }^{35}$ Indeed, it may be argued that as most countries in the region are not signatories to protocols that grant rights to refugees, therefore, no granted rights were ever stripped or taken away. However, although the concept of refugee extends beyond the boundaries and definition of a legal status, it should be noted that a legal status has implications for what opportunities and lives become possible. ${ }^{36}$ Simultaneously, refugees' situations in countries in the region serve as an acute reminder to citizen subjects of the precariousness of their own citizenship status $^{37}$ and what will happen if they face displacement.

The positioning of Palestinian refugees, as permanently temporarily residents, is a crucial issue underlying the subsequent migration and asylum politics developed in the Middle East. However, considering the Palestinian case as an exception, makes it possible to note how developing a rights-based approach for other refugees has been systematically ignored by state actors in the region. ${ }^{38}$ Even the migration of Iraqis after 2003 did not prompt Lebanon, Syria or Jordan to develop a comprehensive framework related to asylum or draft laws to organize asylum processes. State actors in states which have not signed the 1951 Convention and the 1967 protocol, which requires them to grant refugees rights, gain more control over refugees in their ability to take arbitrary actions without legal recourse and few avenues for accountability or protection. Turkey, however, is here an exception, as it has been developing a migration and asylum system since 2005, as part of its EU accession process. This culminated in the passing of Turkey's first law on asylum, Law 6458 on Foreigners and International Protection. In the case of Syrian refugees in Turkey specifically, the Turkish government drafted the Temporary Protection Regulation (2014), which sets Syrian refugees

\footnotetext{
${ }^{33}$ Are Knudsen, "Widening the Protection Gap: The 'politics of Citizenship' for Palestinian Refugees in Lebanon, 1948-2008,” Journal of Refugee Studies, 2009, Vol.22(1), p.51-73; Anis F. Kassim,“The Palestinians: From Hyphenated to Integrated Citizenship.” In Nils A. Butenschon, Uri Davis and Manuel Hassassian(eds.), Citizenship and the State in the Middle East: Approaches and Applications, New York, Syracuse University Press, 2000, p. 201-224.

${ }^{34}$ Are Knudsen, op.cit., 2009.

${ }^{35}$ Nergis Canefe, op.cit., 2018.

${ }^{36}$ Luin Goldring and Patricia Landolt, op.cit., 2013.

${ }^{37}$ Some within the region might argue that this precariousness is visible regardless of refugees due to the ways citizenship politics are played out in countries in the region. The limitations on women passing on citizenship in Lebanon, Jordan and elsewhere highlight a visible boundary to rights as citizens.

${ }^{38}$ Are Knudsen, op.cit., 2009.
} 
in a distinct legal status than other migrants and refugees in Turkey. ${ }^{39}$ While granting Syrian refugees basic rights and access to services, the regulation includes limitations regarding their long-term presence. That is, holding the status of temporary protection is not an avenue to enter citizenship; its continuation or any subsequent status assigned, is subject to the decision of the Turkish Council of Ministers (Temporary Protection Regulation 2014). ${ }^{40}$ The future of those holding this status is not defined by legislation but will be determined by political actors and considerations.

The temporal limitation on the presence of refugees in receiving countries, even if the end date is not clearly articulated, means that refugees face a looming horizon of deportation or expected return. This forecasted horizon of deportation, whether in the near or distant future, recalls De Genova's discussion of deportability. ${ }^{41}$ Where refugee status is expected to ensure a form of long term permanence or protection, the politics of refugee return in the region highlights the blurring of boundaries between refugee and migrant statuses. The temporariness of the refugees' presence - whether due to the law, regulation or policies, or spurred by a lack of these - is another reason to approach the status of refugee and migrant as related, rather than adhere to approaches that mark them as distinct. ${ }^{42,43}$ While this blurring occurs through regulations and in relations with different actors, varying from state actors to employers, who influence the mechanisms of inclusion of non-citizens in various contexts, it is also productive to think of the ways in which the blurring extends to refugees' position as labour. ${ }^{44}$ The following section focuses on how refugees' presence is harnessed as labour power, while recognising the varying drives and dynamics between countries in the region that nuance the incorporation of labour. ${ }^{45}$

\section{The Labouring Refugee in the Middle East and Turkey}

Without legal pathways or political will for refugees to remain in the country, as is the case in Lebanon and Jordan, or with the temporariness of the status granted, as in the Turkish case, refugees' presence is set up as permanently temporary. They face a future of eventual deportation, ${ }^{46}$ although the majority of them will ultimately remain in countries in the region, despite policies or state actors' attempts to send them back. ${ }^{4748}$ For the past decades, Lebanon

\footnotetext{
${ }^{39}$ Directorate General of Migration Management, "Regulation No. 29153 on Temporary protection," adopted October 22, 2014, available at:https:/www.refworld.org/docid/56572fd74.html [Last accessed on 16 December 2019]

${ }^{40}$ Ibid.

${ }^{41}$ Nicholas De Genova, "Migrant "Illegality" and Deportability in Everyday Life," Annual Review of Anthropology, 2002, Vol.31, p.419-447.

${ }^{42}$ While regulation or law may make refugees deportable, refugees themselves will find ways to remain as recognised in the autonomy of migration literature; For an example from Germany of refugees not waiting for the state to organise their lives, see: Moritz Altenried et al., op.cit., 2018.

${ }^{43}$ Prem Kumar Rajaram, op.cit., 2018.

${ }^{44}$ Ibid; Ranabir Samaddar, op.cit., 2017.

${ }^{45}$ Nergis Canefe, op.cit., 2018; Lewis Turner, op.cit., 2015.

${ }^{46}$ See Nicholas De Genova, "Migrant 'Illegality' and Deportability in Everyday Life" Annual Review of Anthropology, 2002, 31, 419-447 for discussion on deportation.

${ }^{47}$ Across the region, the regain of control of the Syrian regime over Syrian territory has resulted in a heightened and increased discourse of Syrian refugees' eventual return, voluntary or through deportation, to Syria. See: International Crisis Group, op.cit., 2020.

${ }^{48}$ Kemal Kirişci and Gokce Uysal Kolasin, "Syrian Refugees in Turkey need Jobs: Why Employing them is more Realistic than Trying to Send them Back," Brookings Institute, September 11, 2019. Available at:
} 
and Jordan have been receiving migrant labourers from diverse places of origin, who are incorporated into specific sectors such as domestic work, construction, industry or agriculture among others. ${ }^{49}$ Migrant incorporation into economic sectors is stratified based on nationality and gender among migrants from Egypt, Syria, Sudan, Ethiopia or South East Asia and other countries. Migrant workers can only work formally in specific sectors and are excluded from accessing certain sectors through labour laws reserving these sectors or specific jobs in sectors for nationals. ${ }^{50}$ In both countries, there is a long standing kafala or sponsorship regime in place that enables the formalisation of migrant labour; however, the possibility of acquiring work permits does not decrease the exploitative nature of labour relations. Similarly, in Turkey, while migrants and refugees are integrated into the local economy as labour, access to work permits is restrictive despite the existence of legislation to formally organize non-citizen labour. ${ }^{51}$ As a result, the majority of migrants and refugees in the Middle East and Turkey work without authorisation and in sectors with high levels of informality such as the textile industry, construction, domestic work and the like. Syrian refugees arriving in Turkey, Lebanon and Jordan after 2011, had to deal with the already hierarchised labour markets and relations.

With the understanding that the conflict in Syria was going to continue for the foreseeable future, various initiatives to facilitate the formalization of refugees' labour were launched after 2015. The Jordan Compact, initiated in 2016, aimed to increase the labour integration of Syrian refugees and Jordanian nationals, while promoting the benefits of this incorporation for Jordan's economic development. ${ }^{52}$ However, as Lenner and Turner explain, the compact ignored local structural considerations concerning migrant labour, such as where refugees were living, gender issues and Syrian refugees' skills. ${ }^{53}$ In Turkey, Syrian refugees faced different patterns of inclusion, depending on the province, sector, and when they came to Turkey. Research that focused on labour intensive sectors, such as the textile or agriculture industries illustrate the ways in which Syrian refugees are included as precarious labour due to the large informality of these sectors, the generally unskilled nature of the work, and the facility of working in these sectors despite not speaking the local language. ${ }^{54}$ Refugees

\footnotetext{
https:/www.brookings.edu/blog/order-from-chaos/2019/09/11/syrian-refugees-in-turkey-need-jobs/ [Last accessed on 19 December 2019]

${ }^{49}$ Katharina Lenner and Lewis Turner, op.cit., 2019; Amrita Pande, “"The Paper That You Have in Your Hand Is My Freedom': Migrant Domestic Work and the Sponsorship (Kafala) System in Lebanon," International Migration Review, 2013, Vol.47(2), p.414-441; John T. Chalcraft, The Invisible Cage: Syrian Migrant Workers in Lebanon, Stanford, Stanford General, 2009.

${ }^{50}$ Katharina Lenner and Lewis Turner, op.cit., 2019; John T. Chalcraft, op.cit., 2009; Lebanon Support, "Syrian Refugees' Livelihoods. The Impact of Progressively Constrained Legislation and Increased Informality on Syrians’ Daily Lives," Beirut, Civil Society Knowledge Center, 2016b, available at:

https:/civilsociety-centre.org/resource/syrian-refugees-livelihoods-impact-progressively-constrained-legislations -and-increased [Last accessed on 1 February 2020]

${ }^{51}$ Didem Danış, Cherie Taraghi and Jean-Francois, "Integration in Limbo: Iraqi, Afghan, Maghrebi and Iranian Migrants in Istanbul,” Istanbul, Koç University, 2005, available at:

http://portal.ku.edu.tr/ mirekoc/reports/2005_2006_didem_danis.pdf [last accessed on xx] ; Gaye Burcu Yildiz, "Foreign Workers in Turkey, Their Rights and Obligations Regulated in Turkish Labour Law," European Journal of Migration and Law, 2007, Vol.9(2), p.207-27.

${ }^{52}$ Katharina Lenner and Lewis Turner, op.cit.., 2019.

${ }^{53}$ Ibid., p.66.

${ }^{54}$ Sinem Kavak, "Syrian Refugees in Seasonal Agricultural Work: A Case of Adverse Incorporation in Turkey," New Perspectives on Turkey, 2016, Vol.54(54), p.33-53; Ximena Vanessa Del Carpio and Mathis Christoph Wagner, "The impact of Syrian refugees on the Turkish labour market (English)," Policy Research working paper, Washington, World Bank Group, 2015, WPS 7402, available at:
} 
arriving to Lebanon faced an already saturated job market with insufficient growth possibilities as well as restrictions on sectors and jobs.

Across the Middle East and Turkey, the labour of refugees has been normalised socially and politically. Similarly, the labour of specific segments of the refugee population has been promoted through refugee relief programs, such as work in the economic zones in Jordan, which are supposedly aimed at reducing the economic effect of refugee presence. ${ }^{56}$ Canefe describes the situation as a form of neo-developmentalism, whereby various state and international actors promote the development of specific skills among refugees in order to meet labour market demands in countries across the region, as part of an effort to match labour demand with labour supply. ${ }^{57}$ Such programs also aim to use funding allocated for refugees to achieve overarching developmental aims, or for improvement of national infrastructures within the countries in which they are carried out.

This partnership of governance and development emerges clearly in the way in which work permits and access to formal employment has been promoted by donor states and other actors. ${ }^{58}$ Paths for refugees to work formally in various countries in the Middle East exist(ed), but none have been developed legally for a non-Palestinian refugee population - except in the case of Turkey. ${ }^{59}$ Lebanon and Jordan have a sponsorship program in place to formally organise migrant labour. ${ }^{60}$ In the case of Jordan it was extended for Syrian refugees in 2016. ${ }^{61}$ As part of the Jordan Compact, Jordanian authorities promised to increase the number of permits that would be issued for Syrian refugees. ${ }^{62}$ While Turkey's work permit system is a somewhat more recent introduction to Turkey's legal system, ${ }^{63}$ the government drafted the Regulation on Work Permits for Foreigners under Temporary Protection (2016) to formalize the labour of refugees under Temporary Protection distinctly from other migrant and refugee

\footnotetext{
http://documents.worldbank.org/curated/en/505471468194980180/The-impact-of-Syrians-refugees-on-the-Turki sh-labour-market [Last accessed on 16 December 2019]; Deniz Pelek, "Syrian Refugees as Seasonal Migrant Workers: Re-Construction of Unequal Power Relations in Turkish Agriculture," Journal of Refugee Studies, 2018, Vol. 32(4), p.605-629.

${ }^{55}$ John T. Chalcraft, op.cit., 2009; Lebanon Support, "Syrian Refugees' Livelihoods. The Impact of Progressively Constrained Legislation and Increased Informality on Syrians' Daily Lives," op.cit.

${ }^{56}$ Katharina Lenner and Lewis Turner,op.cit., 2019; Lewis Turner, op.cit., 2015.

${ }^{57}$ Nergis Canefe, op.cit., 2018.

${ }^{58}$ It should be noted that some of these initiatives appear to perpetuate informal work practices. One example is providing skills training in the form of hairdresser training for women. While this type of training may result in economic productivity, most of the women will work informally. See: Katharina Lenner and Lewis Turner, op.cit., 2019;

${ }^{59}$ The Turkish government released the Regulation on Work Permits of Foreigners under Temporary Protection in January 2016 to organise the formal labour integration of Syrian refugees under Temporary Protection. The regulation is distinct from Turkey's law governing the labour of non-Syrian non-citizens.

${ }^{60}$ Katharina Lenner and Lewis Turner, op.cit., 2019; Lebanon Support, “Syrian Refugees' Livelihoods. The Impact of Progressively Constrained Legislation and Increased Informality on Syrians' Daily Lives," Beirut, Civil Society Knowledge Center, 2016, available at:

https://civilsociety-centre.org/resource/syrian-refugees-livelihoods-impact-progressively-constrained-legislations -and-increased [Last accessed on 1 February 2020].

${ }^{61}$ Katharina Lenner and Lewis Turner, op.cit., 2019; Veronique Barbelet, Jessica Hagen-Zanker, and Dina Mansour-Ille, "The Jordan Compact: Lessons Learnt and Implications for Future Refugee Compacts," London, Overseas Development Institute, 2018, available at: https://www.odi.org/sites/odi.org.uk/files/resource-documents/12058.pdf [last accessed xx].

${ }^{62} \mathrm{Ibid}$.

${ }^{63}$ Gaye Burcu Yildiz, op.cit., 2007.
} 
groups. ${ }^{64}$ In the case of Lebanon, previous bilateral agreements formally allowed Syrians to work in Lebanon for up to one year before having to pay for their work permit. ${ }^{65}$ As of 2015, Syrian refugees wishing to enter the Lebanese labour market must to apply for work permits in the same way as other migrant workers; however Syrian refugees who registered with UNHCR and received UNHCR support were obliged to agree legally that they will not work while in Lebanon. ${ }^{66}$ This approach seeks to entrench the boundaries between Syrian refugees who become labouring bodies and those who receive aid. Attempts to increase the incorporation to formal labour came after 2015, with greater awareness of the protracted nature of the conflict, which indicates a shift for state and international actors towards longer term planning, as well as the intersection of migration and labour governance.

Increasing the quota of work permits to be issued (as in the case of Jordan), and creating the infrastructure for Syrians under Temporary Protection to be able to apply for work permits (as in the case of Turkey) impacts informally employed Syrian refugees; the majority of those working. Similarly, in the case of Lebanon, refugees registered with UNHCR caught working would face legal sanction. ${ }^{67}$ While work permits are upheld as a means to improve work conditions and ensure rights, they also serve as tools to govern who among the refugee population and how many refugees are working. Work permits and legislation governing access to work permits offer further grounds for state actors to fine employers for hiring refugees without permits, and initiate action against informally employed refugees by rendering their work "illegal". ${ }^{68}$ Refugees' position as labour becomes more precarious than it was already, as those working informally then face greater need to remain invisible to state actors. ${ }^{69}$ De Genova argues that the deportation of some migrants due to their "illegal" work acts as a warning and drive to other migrants to hide their presence and labour. ${ }^{70}$ In this case, refugees thus become a more exploitable and desirable labour force, while at the same time becoming a means to gain external, donor and financial support. ${ }^{71}$

The drive to formalise Syrian refugees' labour further highlights the fact that they are permanently temporary in countries across the region. None of the moves to increase formal labour tie labour with a future of presence in the country. ${ }^{72}$ Formal labour never builds

\footnotetext{
${ }^{64}$ Ministry of Labor, "Regulation on Work Permits of Foreigners under Temporary Protection," adopted on January 11, 2016, available at: https://www.refworld.org/docid/582c71464.html [last accessed 16 December 2019]

${ }^{65}$ Lebanon Support, “Syrian Refugees’ Livelihoods. The Impact of Progressively Constrained Legislation and Increased Informality on Syrians' Daily Lives," op.cit.

${ }^{66}$ Ibid.

${ }^{67}$ Ibid.

${ }^{68}$ In the case of Turkey, prior to the passing of the legislation organising access to work permits for Syrian refugees under Temporary Protection, state actors turned a blind eye in many cases to refugees' labour as, in the absence of legislation to organise their labour, it was not possible to consider their labour "illegal" or take action because of their labour (e.g. fining, etc.).

${ }^{69}$ Katharina Lenner and Lewis Turner, op.cit., 2019; Lebanon Support, "Formal Informality, Brokering Mechanisms, and Illegality. The Impact of the Lebanese State's Policies on Syrian Refugees' Daily Lives," Beirut, Civil Society Knowledge Centre, 2016, available at:

https://civilsociety-centre.org/resource/formal-informality-brokering-mechanisms-and-illegality-impact-lebanese -state\%E2\%80\%99s-policies [last accessed 18 February 2020].

${ }^{70}$ Nicholas De Genova, Working the Boundaries: Race, Space, and “Illegality” in Mexican Chicago, Durham, Duke University Press, 2005; Prem Kumar Rajaram, op.cit., 2018.

${ }^{71}$ Fiona B. Adamson and Gerasimos Tsourapas, op.cit., 2019.

${ }^{72}$ In the case of Turkey, Turkish citizenship has been granted to some Syrian refugees. For a discussion about this exceptional citizenship granting, see: Şebnem Köşer Akçapar and Doğuş Şimşek, “The Politics of Syrian
} 
towards the possibility of inclusion as citizens, or even perhaps status as permanent resident, at least in terms of formal regulation. ${ }^{73}$ Refugees' labour in different countries in the region, whether informal or with a permit, is merely focused on preserving or sustaining life. Refugees' labour is then set up with underlying temporal boundaries entrenching their position as surplus labour that will eventually leave. ${ }^{74}$

\section{Conclusion}

This paper poses questions about the ways in which Syrian refugees, and the position of refugees overall, has been formulated in countries across the Middle East, in particular Lebanon and Jordan, as well as Turkey. While recognising variations in practices due to different histories of state formation or politics surrounding citizenship, there is common ground for discussing these countries' responses within the same frame. In approaching the position of Syrian refugees in the region within one frame, the figure of the refugee that emerges, is one close to that of the migrant labourer - both characterised by being permanently temporary, generally without recourse to any long-term status. Moreover, refugees as labour outlines the terms and conditions for their temporary presence in countries in the region.

Various actors, whether state or non-state, attempt to influence not only how the status of refugee is formulated, but also the everyday lived realities of seeking refuge in the region. These different actors are involved in the production of discourses that portray refugees as "other" to citizens - and in the case of Middle Eastern countries, "other" to long standing Palestinian residents. The "othering" of refugees works towards masking economic relations and exploitation faced across citizen and non-citizen lines. In the process of analysing the position of refugees in the region, it becomes necessary to examine the modes of differential inclusion in operation across citizen and non-citizen lines. This mode of incorporation becomes part of discourses surrounding refugee presence, as well as underlying policies and practices that govern refugee populations. The conditionality of refugee presence and the protection offered by states in the region, rather than being an exception, highlights a growing trend of the proliferation of a multiplicity of statuses set to differentially include various populations.

Refugees in Turkey: A Question of Inclusion and Exclusion through Citizenship,” Social Inclusion, 2018, Vol.6(1), p.176-178.

${ }^{73}$ In the case of Turkey, holding a work permit for five years opens the possibility of applying for citizenship or long-term residence. However, this future possibility of permanence is not possible for those who hold it under Temporary Protection.

${ }^{74}$ This is not to argue that refugee labour does not accrue other forms of value in different relations . Sevinin (2019) explains how refugees' unwillingness to accept work, regardless of work conditions, to provide for themselves and their family accrued negative social value among local interlocutors in Denizli. Labour can be transformed into other forms of value, but in the case of this paper, the aim is to highlight the ways it cannot lead to value in the form of long term status or citizenship and the legal stability associated with that. See: Eda Sevinin, "Employing Refugees, Deploying Humanitarian Aid," In Tegiye Birey, Celine Cantat, Ewa Maczynska and Eda Sevinin (eds.), Challenging the Political Across Borders: Migrants and Solidarity Struggles, Budapest, Central European University, 2019. 


\section{Bibliography}

Fiona B. Adamson and Gerasimos Tsourapas, "The Migration State in the Global South: Nationalising, Developmental, and Neoliberal Models of Migration Management," International Migration Review, 2019, p.1-30.

Moritz Altenried et al., "Logistical Borderscapes: Politics and Mediation of Mobile Labour in Germany after the 'Summer of Migration”' South Atlantic Quarterly, 2018, Vol. 117(2), p.291-312.

Ruben Andersson, Illegality, inc.: Clandestine Migration and The Business of Bordering Europe, California Series in Public Anthropology, California,University of California Press, 2014.

Rutvica Andrijasevic,"From exception to excess: detention and deportations across the Mediterranean space.” In Nicholas De Genova and Nathalie Mae Peutz (eds.),The Deportation Regime: Sovereignty, Space, and the Freedom of Movement, Durham, Duke University Press, 2010, p.147-165.

Veronique Barbelet, Jessica Hagen-Zanker, and Dina Mansour-Ille, “The Jordan Compact: Lessons Learnt and Implications for Future Refugee Compacts,” London, Overseas Development Institute, 2018, available at:

https://www.odi.org/sites/odi.org.uk/files/resource-documents/12058.pdf [Last accessed on 16 December 2019].

Nergis Canefe, The Syrian Exodus in Context: Crisis, Dispossession and Mobility in the Middle East. Istanbul, Istanbul Bilgi University Press, 2018.

Ximena Vanessa Del Carpio and Mathis Christoph Wagner, "The impact of Syrian refugees on the Turkish labour market (English)," Policy Research working paper, Washington, World Bank Group, 2015, WPS 7402, available at:

<http://documents.worldbank.org/curated/en/505471468194980180/The-impact-of-Syrian s-refugees-on-the-Turkish-labour-market $>$ [Last accessed on 16 December 2019]

Heidi Castaneda,“Deportation Deferred: “Illegality,” Visibility, and Recognition in Contemporary Germany," In Nicholas De Genova and Nathalie Mae Peutz (eds.), The Deportation Regime: Sovereignty, Space, and the Freedom of Movement, Durham, Duke University Press, 2010, p.245-261.

John T. Chalcraft, The Invisible Cage: Syrian Migrant Workers in Lebanon, Stanford, Stanford General, 2009

Dawn Chatty, Displacement and Dispossession in the Middle East, Cambridge, Cambridge University Press, 2010. 
Didem Danış, Cherie Taraghi and Jean-Francois, "Integration in Limbo: Iraqi, Afghan, Maghrebi and Iranian Migrants in Istanbul," Istanbul, Koç University, 2005, available at: http://portal.ku.edu.tr/ mirekoc/reports/2005_2006_didem_danis.pdf [Last accessed 16 December 2019]

Directorate General of Migration Management, "Regulation No. 1994/6169 on the Procedures and Principles related to Possible Population Movements and Aliens Arriving in Turkey either as Individuals or in Groups Wishing to Seek Asylum either from Turkey or Requesting Residence Permission in order to Seek Asylum From Another Country," adopted on January 19, 1994, available at: http://www.refworld.org/docid/49746cc62.html [Last accessed 16 December 2019]

Directorate General of Migration Management, "Law No. 6458 on Foreigners and International Protection," adopted April 4, 2013, available at: https://www.refworld.org/docid/5167fbb20.html [last accessed 13 December 2019]

Directorate General of Migration Management, "Regulation No. 29153 on Temporary protection," adopted October 22, 2014, available at:https://www.refworld.org/docid/56572fd74.html [Last accessed on 16 December 2019]

Nicholas De Genova, "Migrant "Illegality" and Deportability in Everyday Life," Annual Review of Anthropology, 2002, Vol.31, p.419-447.

Nicholas De Genova, Working the Boundaries: Race, Space, and "Illegality" in Mexican Chicago, Durham, Duke University Press, 2005.

Nicholas De Genova, "The Deportation Regime: Sovereignty, Space, and the Freedom of Movement," In Nicholas De Genova and Nathalie Mae Peutz, The Deportation Regime: Sovereignty, Space, and the Freedom of Movement, Durham, Duke University Press, 2010, p..

Luin Goldring, Carolina Berinstein and Judith K. Bernhard, "Institutionalizing precarious migratory status in Canada," Citizenship Studies, 2009, Vol. 13(1): 239-265.

Luin Goldring and Patricia Landolt, "The Conditionality of Legal Status and Rights: Conceptualising Precarious Non-citizenship in Canada," In Luin Goldring and Patricia Landolt (eds.), Producing and Negotiating Non-Citizenship: Precarious Legal Status in Canada, Toronto,University of Toronto Press, 2013, p. 3-28.

Sabine Hess, "De-naturalising transit migration. theory and methods of an ethnographic regime analysis,” Population, Space and Place, 2010, Vol. 18(4), p.428-440.

International Crisis Group, "Easing Syrian Refugees' Plight in Lebanon," Brussels, International Crisis Group, 2020, p.211. Available from: https://www.crisisgroup.org/middle-east-north-africa/eastern-mediterranean/lebanon/211easing-syrian-refugees-plight-lebanon [Last accessed on 19 February 2020]

Anis F. Kassim, 2000. “The Palestinians: From Hyphenated to Integrated Citizenship.” In Nils A. Butenschon, Uri Davis and Manuel Hassassian, Citizenship and the State in the Middle East: Approaches and Applications, New York, Syracuse University Press, 2000, p. 201-224. 
Sinem Kavak,"Syrian Refugees in Seasonal Agricultural Work: A Case of Adverse Incorporation in Turkey,” New Perspectives on Turkey, 2016, Vol.54(54), p.33-53.

Kemal Kirişci and Gokce Uysal Kolasin, "Syrian Refugees in Turkey need Jobs: Why Employing them is more Realistic than Trying to Send them Back," Brookings Institute, September 11, 2019. Available at:

https://www.brookings.edu/blog/order-from-chaos/2019/og/11/syrian-refugees-in-turkeyneed-jobs/ [Last accessed on 19 December 2019]

Are Knudsen, "Widening the Protection Gap: The 'politics of Citizenship' for Palestinian Refugees in Lebanon, 1948-2008," Journal of Refugee Studies, 2009, Vol.22(1), p.51-73.

Şebnem Köşer Akçapar and Doğuş Şimşek, 2018. "The Politics of Syrian Refugees in Turkey: A Question of Inclusion and Exclusion through Citizenship” Social Inclusion, 2018, Vol.6(1), p.176-178.

Lebanon Support, "Syrian Refugees' Livelihoods. The Impact of Progressively Constrained Legislation and Increased Informality on Syrians' Daily Lives,” Beirut, Civil Society Knowledge Center, 2016b, available at:

https://civilsociety-centre.org/resource/syrian-refugees-livelihoods-impact-progressively-co nstrained-legislations-and-increased [Last accessed on 1 February 2020]

Lebanon Support, "Formal Informality, Brokering Mechanisms, and Illegality. The Impact of the Lebanese State's Policies on Syrian Refugees' Daily Lives,” Beirut, Civil Society Knowledge Centre, 2016a, available at:

https://civilsociety-centre.org/resource/formal-informality-brokering-mechanisms-and-illeg ality-impact-lebanese-state\%E2\%80\%99s-policies [last accessed 18 February 2020].

Katharina Lenner and Lewis Turner"Making Refugees Work? The Politics of Integrating Syrian Refugees into the Labour Market in Jordan.” Middle East Critique, 2019, Vol.28(1), 65-95.

Sandro Mezzadra and Brett Neilson, Border as Method, or, the Multiplication of Labor, Durham, Duke University Press, 2013.

Ministry of Labor, "Regulation on Work Permits of Foreigners under Temporary Protection," adopted on January 11, 2016, available at: https://www.refworld.org/docid/582c71464.html [Last accessed 16 December 2019]

Amrita Pande, “'The Paper That You Have in Your Hand Is My Freedom': Migrant Domestic Work and the Sponsorship (Kafala) System in Lebanon," International Migration Review, 2013, Vol.47(2), p.414-441.

Dimitris Papadopoulos, Niamh Stephonson and Vassilis Tsianos, Escape Routes: Control and Subversion in the Twenty-First Century, London, Pluto Press, 2008.

Deniz Pelek, "Syrian Refugees as Seasonal Migrant Workers: Re-Construction of Unequal Power Relations in Turkish Agriculture,” Journal of Refugee Studies, 2018, Vol. 32(4), p.605-629.

Prem Kumar Rajaram, "Refugees as Surplus Population: Race, Migration and Capitalist Value Regimes,” New Political Economy, 2018, Vol. 23(5), p.627-639. 
Deepa Rajkumar et al., "At the Temporary-Permanent Divide: How Canada Produces Temporariness and Makes its Citizens Through its Security, Work and Settlement Policies," Citizenship Studies, 2012, Vol. 16(3-4), p.485-510

Ranabir Samaddar,“The Labour of the Refugee Economies,” Website, Refugee Watch, 2017, available at:

https://refugeewatchonline.wordpress.com/2017/04/14/the-labour-of-the-refugee-economi es/ [Last accessed on 16 December 2019]

Eda Sevinin, "Employing Refugees, Deploying Humanitarian Aid," In Tegiye Birey, Celine Cantat, Ewa Maczynska and Eda Sevinin (eds.), Challenging the Political Across Borders: Migrants and Solidarity Struggles, Budapest, Central European University, 2019, p.193-222.

Michal Sipos, “'We are all brothers here': The making of a life by Chechen refugees in Poland," Population, Space and Place, e2276, p.1-11.

Lewis Turner, "Explaining the (Non-)Encampment of Syrian Refugees: Security, Class and the Labour Market in Lebanon and Jordan,” Mediterranean politics, 2015, Vol. 20(3), p. 386-484.

Gaye Burcu Yildiz, "Foreign Workers in Turkey, Their Rights and Obligations Regulated in Turkish Labour Law," European Journal of Migration and Law, 2007, Vol.9(2), p.207-27. 